\title{
Short Duration Grazing at the Texas Experi- mental Ranch: Weight Gains of Growing Heifers
}

\author{
R.K. HEITSCHMIDT, J.R. FRASURE, D.L. PRICE, AND L.R. RITTENHOUSE
}

\begin{abstract}
Total and average daily gains of Hereford/Angus crossbred growing heifers were contrasted between a continuously grazed (CG) treatment and a 10-pasture, 1-herd rapidly rotated short duration grazing (SDG) treatment. Stocking rate in the CG was $0.48 \mathrm{ha} / \mathrm{AUM}$, a moderate rate, while stocking rate in the SDG treatment was 0.24 ha/AUM. Trials were conducted during the 1978 and 1979 growing seasons. Both total and average daily gains were similar in both treatments both years. Because of the two-fold difference in rate of stocking, production/ha was approximately double in the SDG to that in the CG treatment. It is tentatively concluded from the results of this and previous studies that a properly managed SDG system may satisfactorily support livestock at rates of stocking appreciably greater than that normally expected from conventional grazing schemes.
\end{abstract}

Interest in multi-pasture, one-herd short duration grazing (SDG) systems has dramatically increased in the United States within the past decade. Of particular interest has been the claim that proper implementation of a SDG system will, as a rule, result in a two-fold increase in livestock carrying capacity (Savory 1978). However, quantitative data supporting this claim are scarce and most published reports do not indicate a significant improvement in livestock production following implementation of specialized grazing systems (Lewis 1969, Herbel 1974, Launchbaugh et al. 1978, Gammon 1978) although notable exceptions do occur (Merrill 1954). It should be noted, however, that most grazing system studies have been conducted at only moderate to heavy rates of stocking and thus the opport unity to increase livestock production dramatically per unit area of land has been limited (Gammon 1978). In addition, it should be emphasized that most grazing systems previously advocated require relatively little managerial input in that scheduled movement of livestock was usually by calendar date. The method of SDG advocated by Savory (1978) requires intensive management in that livestock movement and rates of stocking are flexible based on both the nutritional needs of the livestock and vegetative growth parameters.

We conducted a grazing trial at the Texas Experimental Ranch during the 1978 and 1979 growing seasons to evaluate the effects of SDG on vegetation growth dynamics and livest ock weight gains at a rate of stocking appreciably greater than normal. Weight gains of growing heifers were contrasted between a continuously grazed (CG) treatment stocked at a moderate rate and a 10-pasture SDG

Authors are associate professor and former research associates, Department of Range Science, Texas A\&M Univ. Res. and Ext. Center, Box 1658, Vernon, 76384 and associate professor, Department of Range Science, Colorado State University, Fort Collins, 80523

Appreciation is expressed to the Swen R. Swenson, Cattle Company for providing the land, livestock and facilities for this research project.

Report is published with approval of the Director, Texas Agricultural Experiment Station as TA 16356 . treatment stocked at a rate double that of the continuous system. Vegetation parameters were contrasted between an ungrazed control and the SDG treatment. The objectives of this paper are to review current literature related to SDG systems and to report on the weight gains of the growing heifers. Subsequent papers report on the effect of the SDG treatment on vegetative growth dynamics and forage quality (Heitschmidt et al. 1982a, 1982b).

The often controversial method of SDG described by Savory (1978) differs from most methods in that rate of stocking is heavier, number of subdivisions is greater, and rate of herd rotation is faster. Although the effect of each of these factors on livestock performance and vegetation response has been investigated previously (Gammon 1978), studies of the complex interaction effects are limited. The magnitude of this problem is even greater if results from one locale are not applicable to other vegetation types and/or climatic regions. Thus, it is imperative that the underlying principles of SDG be understood in order to implement a SDG system successfully. The following review is an attempt to identify conceptually the basic principles of grazing management which might permit a two-fold increase in livestock carrying capacity with the Savory method.

First, we assume that the three major factors whereby a dramatic increase in carrying capacity may be possible are: (1) increased forage production; and/or (2) increased forage quality; and/or (3) increased efficiency of harvest by the grazing animal. For discussion purposes we define forage production as quantity of forage available to the grazing animal. Forage quality is defined as any forage parameter altering the net energy gain of the grazing animal. Efficiency of harvest is a relative measure of the ability of the grazing animal to consume the available forage.

Increased forage production may be realized on a long-term basis if a shift in species composition toward more productive species occurs. Under CG regimes this is not normally expected at heavy rates of stocking (Sims et al. 1978) and at present there is little quantitative data substantiating the longterm effects of short duration grazing on vegetative composition (Gammon 1978). However, on a short-term basis increases in forage production have of ten resulted in conjunction with either actual (McNaughton 1976, Heitschmidt et al. 1982a) or simulated grazing (Jameson 1963, Gifford and Marshall 1973, Painter and Detling 1981). The mechanisms responsible for these increases may vary from changes in photosynthetic rates and rate of leaf senescence to direct stimulation of growth by substrates in ruminant saliva (McNaughton 1979). A general hypothesis that an optimal grazing scheme does exist whereby a facilitation of energy flow through grassland ecosystems can be realized (Dyer 1975, McNaughton 1979) is currently being extensively examined by several researchers (McNaughton 1979, Detling et al. 1979a, 1979b, Dyer et al. 1981). An underlying hypothesis to this general hypothesis is that produc- 
tivity increases in conjunction with certain levels of herbivory.

Quality of diet of a grazing animal is directly related to quality of available forage (Lesperance et al. 1960, Cook and Harris 1968, Galt et al. 1969, Anderson 1977, Allison and Kothmann 1979). Although quality of forage is a function of many factors, the principal factor altering quality is the physiological age of plant tissue (Streeter et al. 1968, Sims et al. 1971, Wallace et al. 1972, Heitschmidt et al. 1982b) in that young, actively growing tissue is of higher nutritional quality than older, senesced tissue. Thus, livestock consumption of green actively growing tissue as opposed to senesced tissue, will facilitate energy flow through a grazing system since "energy losses" resulting from plant respiratory processes will be reduced as will quantity of energy flowing through the detrital food chain.

Efficiency of harvest by the grazing animal may be improved by increasing percentage of total available forage consumed. Efficiency of harvest will increase in conjunction with increasing grazing pressure but quality of diet will decline when the grazing pressure becomes so intense that the grazing animal is forced to consume less nutritional forage (Spedding 1965, Hodgson 1966, Greenwood and Arnold 1968, Hodgson and Ollerenshaw 1969, Morris 1969, Allison and Kothmann 1979). In addition, excessive grazing pressure can eventually destroy the forage resource as is evident on rangelands throughout the world where overgrazing has been practiced. Presumably this results because the more preferred plants are more severely and more frequently defoliated than the less preferred plants. Since severity and frequency of tiller defoliation can be controlled with SDG, cfficiency of harvest by the grazing animal is the principal factor on which the concept of SDG is based, although such factors as trampling and distribution of dung may also play important roles. Alterations in forage production and/or forage quality, either positive or negative, can only be affected by frequency and severity of tiller defoliation. However, the interaction effects between efficiency of harvest, forage production and forage quality and the grazing animal are extremely complex. Thus conclusions derived from studies evaluating the effect of any single manipulative factor of a SDG system (e.g., length of graze, length of rest, rate of stocking, and livestock density) may not be applicable when any other factor is changed.

Booysen and Tainton (1978) identified SDG systems as either high utilization grazing (HUG) whereby emphasis was on nonselective grazing (Acocks 1966) or as high production and high performance grazing (HPG) whereby emphasis was on controlled selective grazing. Basically, in a SDG system utilizing HUG principles carrying capacity is increased by increasing utilization of the less palatable plants. In a system incorporating HPG principles, carrying capacity is increased because of increased forage production induced by grazing. Range condition is presumably maintained in the HUG system because all plants remain on essentially the same competitive level following each grazing event. However, an implied assumption in this system is that partial defoliation of the less desirable plants is as detrimental to them as complete defoliation of the desirable plants (Booysen 1969). It is doubtful this is true during periods of active growth (Noy-Meir 1976). Range condition in the HPG system is maintained because the non-grazed plants presumably will become moribund while the grazed plants will flourish.

The Savory method of SDG apparently follows HPG principles more closely than HUG principles during periods of active growth with HUG principles followed during periods of dormancy. Length of grazing period is necessarily short to minimize forced grazing resulting in limited intake (Voisin 1959, Broster et al. 1963, Greenhalgh et al. 1966, Marsh 1977, Denny and Barnes 1977) and/or consumption of lower quality forage (Voisin 1959, Allison and Kothmann 1979) and to prevent excessive removal of live photosynthetic tissue whereby regeneration time is excessive (Voisin 1959, Noy-Meir 1976). Adequate deferment of a pasture is necessary following each grazing event to permit plants an opportunity to replenish reserves (Voisin 1959) particularly leaf photosynthetic tissue for "carbon gain capacity" (Detling et al. 1979b).
Hilbert et al. (1981) developed a mathematical model based on the assumption that a proper level of defoliation would increase the average relative growth rate (RGR) of a plant (Gifford and Marshall 1973, Detling et al. 1979b, Painter and Detling 1981). Model output indicated plants could potentially sustain heavier grazing when RGR was low than high. These results suggest that rate of rotation in a SDG system should be more rapid during the most active portion of the growing season than during the dormant season. This rapid rate of rotation also permits livestock to return to a previously grazed pasture prior to the senescence of plant regrowth tissue which reduces forage quality (Rogler 1951, Voisin 1959, Smoliak 1960, Bodgan and Kidner 1967, Heitschmidt et al. 1982b).

Rapid rotation of livestock may also prove to enhance the efficiency of livestock to harvest more plant species, particularly the short-lived annual grasses and forbs. If rate of rotation is too slow, many highly preferred annual plants may not be utilized in certain pastures because they will have reached an advanced stage of maturity prior to the livestock being permitted to graze them.

The effect of stocking rate in SDG systems is difficult to assess. Pattern of tiller defoliation will obviously change if stocking rate is significantly increased and all other factors remain constant. Gammon and Roberts (1978a, 1978b, 1978c) contrasted grazing selectivity and frequency and severity of defoliation of tillers between OCG treatment stocked at a moderate rate and a SDG treatment stocked at a rate approximately $10 \%$ greater. Length of grazing period was 6 to 12 days in the SDG treatment. Results indicated minimal differences in pattern of defoliation between treatments with $90 \%$ of the marked tillers in both treatments receiving two or less defoliations during the study. Results also indicated forage production was not affected by grazing treatment (Gammon and Roberts 1978d). This would be expected since pattern of tiller defoliation was similar. Heavier stocking rates may have increased forage production since significant increases in stocking rates have been hypothesized to be a necessity to increase forage production in SDG systems in certain instances (Heitschmidt et al. 1982a). The question remains as to whether such an increase in stocking rate will result in defoliation of a greater number of plant species (HUG) or a greater number of tillers of the same species (HPG).

Density of livestock at any given rate of stocking is a direct function of number of subdivisions. Assuming length of rotation cycle remains constant, then increasing number of subdivisions will reduce period of stay and increase period of absence in any given subdivision. A two-fold increase in number of subdivisions will decrease period of stay 50\% and Booysen et al. (1974) argued that the benefits from greater than eight subdivisions would be minimal because absolute reductions in length of graze would necessarily be small if length of rotation cycle remained constant. Morley (1968) reported little advantage could be derived by increasing number of subdivisions beyond nine. His conclusion was based on vegetative growth curves representing the entire vegetative complex of a pasture but inclusion of species specific growth curves and a selective grazing function in his models may have altered his conclusion. Savory (1978) advocated greater number of subdivisions to increase stocking density, shorten period of stay, and increase hoof action and uniformity of dung distribution. He suggested for example, that a reduction in period of stay from 8 to 4 days is important to optimize performance of both the livestock and vegetation. We hypothesize that increasing the number of subdivisions will be important only if the pattern of defoliation is altered such that increased forage production and/or forage quality is realized by the time of the next grazing event or that the efficiency of harvest by the grazing animal is improved.

Although numerous grazing trials have been conducted attempting to evalua te the merits of various SDG systems over CG or other specialized grazing systems, conclusive scientific evidence supporting or refuting the Savory method of SDG has not been established (Gammon 1978). Although increases in livestock production have been reported from SDG, these have generally only resulted at 
higher stocking rates (Conway 1963, McMeekan and Walshe 1963, Walker 1968, Robinson and Simpson 1975, Denny et al. 1977, Denny and Barnes 1977, Denny and Steyn 1977). There are several possible explanations for the lack of scientific evidence supporting or refuting the Savory method of SDG. A major problem appears to center on experimental design. Most SDG trials have been designed to evaluate the effect of only one or two variables. Because of the obvious interaction effects existing between frequency and severity of tiller defoliations and length of grazing period, length of rest, livestock density and stocking rate, it is critical that the basic effects of each be understood prior to initiating a SDG trial. To address just four factors would require a $4 \times 4$ factorial design. Under native range conditions the inherent variability in vegetation types between pastures, assuming herd sizes were sufficient to obtain acceptable livestock production data, would make data interpretation difficult.

A second problem encountered with experimental designs involves the rigidly scheduled movement of animals. Since vegetation growing conditions are highly variable throughout a calendar year, rate of rotation must also be varied. We assume both HUG and HPG principles will necessarily by utilized over a calendar year in a properly managed SDG system stocked at a heavy rate. However, utilization of the incorrect principle at the wrong time of year could be disastrous.

Finally, we hypothesize that ease of herd movement is critical if livestock production data are the fundamental criterion utilized in an experiment. If a herd is rotated to a new pasture on the average of once every week, 52 movements a year would be required. Obviously this many moves could create a stress of sufficient magnitude to significantly reduce livestock weight gains. This facet of SDG has not been scientifically researched but it may prove to be a key factor regulating livestock weight gains in a SDG system utilizing the Savory method of grazing (Kothmann 1980).

\section{Study Area and Methods}

The study was conducted at the Texas Experimental Ranch located $\left(99^{\circ} 14^{\prime} \mathrm{W}, 33^{\circ} 20^{\prime} \mathrm{N}\right)$ in the northern Rolling Plains. The continental climate of the region is semiarid with annual precipitation at the ranch averaging approximately $700 \mathrm{~mm}$ (unpublished). Ths mixed prairie vegetation of the region is dominated by various combinations of short and midgrasses.

Grazing treatments studied were: continuous grazing (CG) stocked at a moderate rate of 0.48 ha/AUM; and, short duration grazing (SDG) stocked at a rate of 0.24 ha/AUM. The trial was run for 2 years from early April to early October. Both treatments were stocked with Hereford/Angus crossbred heifers that initially weighed $210 \mathrm{~kg}$ in 1978 and $269 \mathrm{~kg}$ in 1979. The two 20.2-ha CG pastures were each stocked with seven heifers while the ten 4.0 -ha SDG pastures were rotationally grazed by 28 heifers. Length of grazing period in the SDG pastures ranged from 3 days during periods of rapid vegetative growth to 7 days during summer dormancy. This resulted in deferment periods ranging from 35 to 42 days. All heifers were weighed at the completion of each SDG rotation cycle. The heifers in the two CG pastures were switched on each weigh date to eliminate the effects of any pasture differences.

All study pastures were located in an 81-ha block with the 10 SDG pastures located between the two CG pastures. All pastures were considered to be nearly equal in carrying capacity when the trial was initiated. The dominant range sites in the block were Clay Loam and Shallow, and overall range condition was considered good. The two dominant grasses in the study pastures were sideoats grama [Bouteloua curtipendula (Michx.) Torr.] and Texas wintergrass (Stipa leucotricha Trin. and Rupr.) (Anderson 1977). For a more complete description of the study area see Heitschmidt et al. (1982a).

Treatment means of average daily gains (ADG) were subjected to normal analysis of variance procedures with mean separation following Tukey $Q$ procedures (Snedecor and Cochran 1967). Model variables were year, grazing treatment, dates, and all associated first order interactions.

\section{Results and Discussion}

The statistical analyses of ADG revealed no significant $(P<0.01)$ year, treatment, or first order interaction effects. Significant differences did occur among dates, with greatest ADG occurring in April and May and lowest occurring in August (Table 1). Weight gains both years paralleled vegetational growth dyna mics (Heitschmidt et al. 1982a) in that the most rapid rate of vegetative growth occurred in the spring and the slowest rates occurred during summer.

Although treatment differences in ADG were not statistically significant, an appreciable difference did occur from August 31 to October 10 in 1978 (Table 1) when ADG averaged $0.39 \mathrm{~kg}$ in the CG treatment and $0.75 \mathrm{~kg}$ in the SDG treatment. Initially, it was assumed that this difference resulted because of a greater abundance of live material in the SDG treatment relative to total standing crop. However, clipped forage estimates from the SDG treatment in 1978 and 1979 (Heitschmidt et al. 1982a) indicated only minor differences between years in September live/dead ratios. Ratios were 0.54 and 0.49 with total standing crops averaging 124 and $126 \mathrm{~g} / \mathrm{m}^{2}$ in 1978 and 1979 , respectively. Similar calculations from standing crop data in an adjacent ungrazed treatment indicated live/dead ratios of 0.35 and 0.39 in 1978 and 1979 , respectively, with corresponding total standing crops averaging 203 and $227 \mathrm{~g} / \mathrm{m}^{2}$. Unless the magnitude of differences in live/dead ratios between 1978 and 1979 in the CG treatment were greater than those in the ungrazed and the SDG treatments, this explanation for the observed differences bet ween years in the ADG in the CG treatment seems highly improbable.

A more likely explanation may be related to the findings of Willoughby (1959). He reported that quantity of total standing crop in a Phalaris tuberosa-subterranean clover-volunteer grass pasture did not affect gains of wethers providing green biomass was present. However, during periods of slow growth a small increase in green biomass dra matically increased both weight gains and wool production. In light of this work it is interesting to note that quantity of live biomass and live/dead ratios were dramatically increasing in September of 1978 but declining in September

Table 1. Average daily gain ( $\mathrm{kg}$ ) between weigh dates of growing heifers in continuous (CG) and short duration grazing (SDG) treatments at Texas Experimental Ranch during 1978 and 1979.

\begin{tabular}{|c|c|c|c|c|c|}
\hline \multirow[b]{2}{*}{ Weigh dates ${ }^{1}$} & \multicolumn{2}{|c|}{1978} & \multicolumn{2}{|c|}{1979} & \multirow[b]{2}{*}{$\bar{X}^{2}$} \\
\hline & CG & SDG & CG & SDG & \\
\hline Apr. 12-May 15 & $1.12 \pm 0.10^{3}$ & $1.23 \pm 0.03$ & $1.01 \pm 0.04$ & $0.82 \pm 0.03$ & $1.02_{a}$ \\
\hline May $15-J u n e ~ 18$ & $0.38 \pm 0.06$ & $0.49 \pm 0.03$ & $0.49 \pm 0.04$ & $0.43 \pm 0.03$ & $0.44_{b c}$ \\
\hline June 18 -July 23 & $0.80 \pm 0.02$ & $0.62 \pm 0.03$ & $0.41 \pm 0.08$ & $0.34 \pm 0.03$ & $0.54 b$ \\
\hline July 23-Aug. 31 & $0.18 \pm 0.05$ & $0.14 \pm 0.01$ & $0.11 \pm 0.07$ & $0.19 \pm 0.03$ & $0.16_{c}$ \\
\hline Aug. 31-Oct. 7 & $0.39 \pm 0.03$ & $0.75 \pm 0.03$ & $0.95 \pm 0.06$ & $0.75 \pm 0.04$ & $0.68_{\mathrm{ab}}$ \\
\hline
\end{tabular}

'Average weigh dates over 2 years. All weigh dates were within 3 days of average.

${ }^{2}$ Means followed by same letter are not significantly different at $P<0.05$.

${ }^{3}$ One standard error of the mean. 


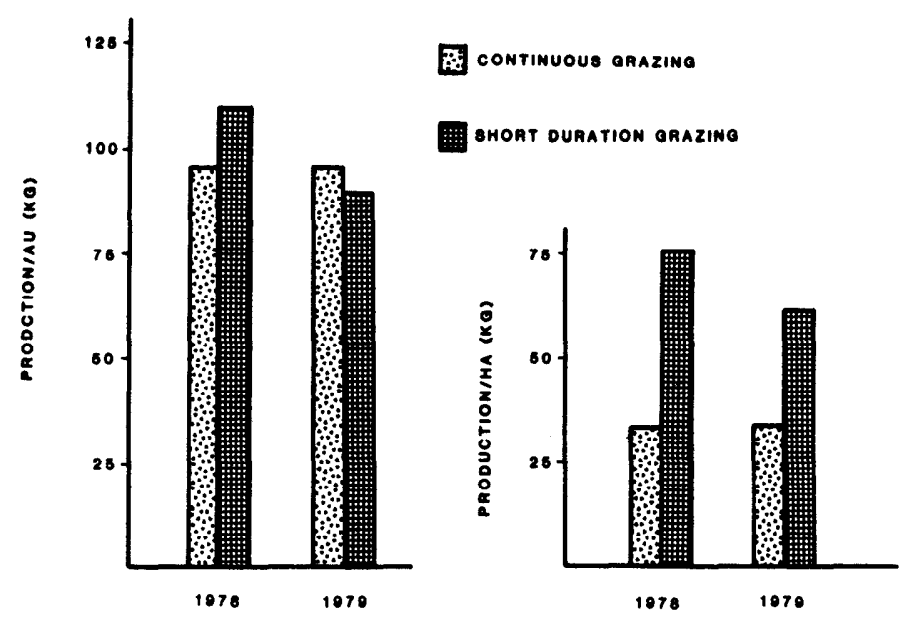

YEAA

Fig. 1. Production/animal and production/ha of growing heifers during 1978 and 1979 from the continuously grazed treatment and the 10pasture, l-herd short duration grazing treatment.

1979 (Heitschmidt et al. 1982a). The interaction effect of these parameters on ADG are purely speculative at this time but field observations suggest these interactions may prove important and future research is being focused in this direction.

Regardless of the reason for the minor treatment differences in ADG of the individual animals over various time periods (Table 1), it is remarkable that total weight gain per animal was similar in both treatments both years (Fig. I). Because of the double stocking rate in the SDG treatment, total production/ha in the SDG treatment was nearly double that in the CG treatment (Fig. I).

\section{Conclusions}

From a review of the literature and the results of this study, we suggest that a SDG system may possibly support livestock at a rate of stocking appreciably greater than that normally expected with continous grazing. We forward this basic conclusion cognizant of the many constraints bounding our experimental design such as conducting the trial only during the growing season. But these data should encourage further investigations of SDG principles particularly with regards to the Savory method of grazing. Such studies should focus on developing a sound scientific understanding of the grazing principles involved in SDG since successful implementation of a SDG system at a rate of stocking appreciably greater than normal will obviously require that management personnel possess a more thorough understanding of grazing management principles than ever before.

\section{Literature Cited}

Acocks, J.P.H. 1966. Non-selective grazing as a means of veld reclamation. Proc. Grassland Soc. S. Afr. 1:33-39.

Allison, C.D., and M.M. Kothmann. 1979. Effect of level of stocking pressure on forage intake and diet quality of range cattle. Proc. West Sect. Amer. Soc. Anim. Sci. 30:174-178.

Anderson, D.M. 1977. Standing crop, diets, travel and weight changes under short-duration and continuous grazing. Ph.D. Diss. Texas A\&M Univ., College Station. 181 p.

Bodgan, A.V., and E.M. Kidner. 1967. Grazing natural grassland in western Kenya. E. Afr. Agr. Forest. J. 33:31-34.

Booysen, P. De V. 1969. An analysis of the fundamentals of grazing management systems. Proc. Grassland Soc. S. Afr. 4:84-91.

Booysen, P. De V., and Neil M. Tainton. 1978. Grassland management: Principles and practices in South Africa. p. 55I-554. In: Proc. Ist Internat. Rangeland Cong. (Ed. by D.N. Hyder) Soc. Range Manage. Denver, Colo.

Booysen, P. De V., J.R. Klug, and B.S. York. 1974. Number of camps for rotational grazing of veld. Proc. Grassland Soc. S. Afr. 9:145-148.
Broster, W.H., V.J. Tuck, and C.C. Balch. 1963. Effect of rationing grass on the growth rate of dairy heifers and on output per acre, with a note on its significance in experimental design. J. Agr. Aci. 60:371-380.

Conway, A. 1963. Effect of grazing management on beef production. II. Comparison of three stocking rates under two systems of grazing Irish $\mathbf{J}$. Agr. Res. 2:243-257.

Cook, C.W., and L.E. Harris. 1968. Nutritive value of seasonal ranges. Utah Agr. Exp. Sta. Bull. No. 472.55 p.

Denny, R.P., and D.L. Barnes. 1977. Trials of multi-paddock grazing systems on veld. 3. A comparison of six grazing procedures at two stocking rates. Rhodesia J. Agr. Res. 15:129-142.

Denny, R.P., D.L. Barnes, and T.C.D. Kennan. 1977. Trials of multipaddock grazing systems on veld. 1. An exploratory trial of systems involving 12 paddocks and one herd. Rhodesia J. Agr. Res. 15:11-23.

Denny, R.P., and J.S.H. Steyn. 1977. Trials of multi-paddock grazing systems on veld. 2 . A comparison of a 16 paddocks-to-one-herd system with a four paddocks-to-one-herd system using breeding cows. Rhodesia J. Agr. Res. 15:119-127.

Detling, J.K., M.I, Dyer, and D.T. Winn. 1979a. Effect of simulated grasshoppers grazing on $\mathrm{CO}_{2}$ exchange rates of western wheatgrass leaves. J. Econ. Entomol. 72:403-406.

Detling, J.K., M.I. Dyer, and D.T. Winn. 1979b. Net photosynthesis, root respiration, and regrowth of Bouteloua gracilis following simulated grazing. Oecologia 41:127-134.

Dyer, M.I. 1975. The effects of red-winged blackbirds (Agelaium phoenicus L.) on biomass production of corn grains (Zea mays L.). J. Appl. Ecol. 12:719-726.

Dyer, M.I., J.K. Detling, D.C. Coleman and D.W. Hibert. 1982. The role of herbivores in grasslands. In: Grasses and grasslands: Systematics \& Ecology. (Ed. by J. R.Estes, R.J. Tyrl and J.M. Brunken) Univ. Oklahoma Press, Norman. p. 255-295.

Galt, H.D., B. Theurer, J.H. Ehrenreich, W.A. Hale, and S.C. Martin. 1969. Botanical composition of diets of steers grazing a desert grassland range. J. Range Manage. 22:14-19.

Gammon, D.M. 1978. A review of experiments comparing systems of grazing management on natural pastures. Proc. Grassland Soc. S. Afr. 13:75-82.

Gammon, D.M., and B.R. Roberts. 1978a. Patterns of defoliation during continuous and rotational grazing of the Matopos sandveld of Rhodesia. 1. Selectivity of grazing. Rhod. J. Agr. Res. 16:117-131.

Gammon, D.M., and B.R. Roberts. 1978b. Patterns of defoliation during continuous and rotational grazing of the Matopos sandveld of Rhodesia. 2. Severity of defoliation. Rhod. J. Agr. Res. 16:133-145.

Gammon, D.M., and B.R. Roberts. 1979c. Patterns of defoliation during continuous and rotational grazing of the Matopos sandveld of Rhodesia. 3. Frequency of defoliation. Rhod. J. Agr. Res. 16:147-164.

Gammon, D.M., and B.R. Roberts. 1978d. Characteristics of herbage on offer during continuous and rotational grazing of the Matopos sandveld of Rhodesia. Rhod. J. Agr. Res. 16:3-22.

Gifford, R.M., and C. Marshall. 1973. Photosynthesis and assimilate distribution on Lolium multiflorum Lan. following differential tiller defoliation. Aust. J. Bio. Sci. 26:517-526.

Greenhalgh, J.F.D, G.W. Reid, J.N. Aitken, and E. Florence. 1966. The effects of grazing intensity on herbage consumption and animal production. I. Short-term effects in strip-grazed dairy cows. J. Agr. Sci. 67:1323.

Greenwood, E.A.N., and G.W. Arnold. 1968. The quantity and frequency of removal of herbage from an emerging annual grass sward by sheep in a set-stocked system of management. J. Br. Grassland Soc. 23:144-148.

Heitschmidt, R.K., D.M. Price, R.A. Gordon, and J.R. Frasure. 1982. Short duration grazing at the Texas Experimental Ranch: Effects on aboveground net primary production and seasonal growth dynamics. J. Range Manage. 35:367-372.

Heitschmidt, R.K., R.A. Gordon, and J.S. Bluntzer. 1982.b Short duration grazing at the Texas Experimental Ranch: Effects on forage quality. J. Range Manage. 35:372-374.

Herbel, Carlton H. 1974. A review of research related to development of grazing systems of native ranges of the western United States. U.S. Dep. Agr. Agr. Res. Div., Plant Sci., Div., Jornada Exp. Range Ret. No. 3.32 p.

Hilbert, D.W., D.M. Swift, J.K. Detling, and M.I. Dyer. 1981. Relative growth rates and the grazing optimization hypothesis. Oecologia 51:1418.

Hodgson, J. 1966. The frequency of defoliation of individual tillers in a set-stocked sward. J. Br. Grassland Soc. 21:258-263.

Hodgson, J., and J.H. Ollerenshaw. 1969. The frequency and severity of defoliation of individual tillers in set-swards. J. Br. Grassland Soc. 24:226-234. 
Jameson, Donald A. 1963. Responses of individual plants to harvest. Bot. Rev. 29:532-594.

Kothmann, M.M. 1980. Consideration of livestock needs in designing grazing systems for rangelands. p. 78-90. In: Digestive Physiology and Nutrition of Ruminants. Vol. 3. Practical nutrition (Ed. by D.C. Church). O\&M Bocks. Corvallis, Ore.

Launchbaugh, John L., Clenton E. Owensby, Frank L. Schwartz, and Larry R. Corah. 1978. Grazing management to meet nutritional and functional needs of livestock. p. 541-546. In: Proc. Ist Internat. Rangeland Cong. (Ed. by D.N. Hyder) Soc. Range Manage. Denver, Colo.

Lesperance, A.L., V.R. Bohman, and D.W. Marble. 1960. Development of techniques for evaluating grazed forage. J. Dairy Sci. 43:682-689.

Lewis, James K. 1969. Range management viewed in an ecosystem framework. p. 97-187. In: The Ecosystem Concept in Natural Resource Management. Academic Press. New York.

Marsh, R. 1977. The effect of level of herbage dry matter per animal on efficiency of utilization of pasture by young Friesian cattle. Proc. New Zcaland Soc. Anim. Prod. 37:62-66.

McMeekan, C.P., and M.M. Walshe. 1963. The inter-relationships of grazing method and stocking rate in the efficiency of pasture utilization by dairy cattle. J. Agr. Sci. Comb. 61:147-163.

McNaughton, S.J. 1976. Serengeti migratory wildebeest: Facilitation of energy flow by grazing. Science 191:92-94.

McNaughton, S.J. 1979. Grazing as an optimization process: Grassungulate relationships in the Serengeti. Amer. Natur. 113:691-703.

Merrill, Leo B. 1954. A variation of deferred rotation grazing for using under southwest range conditions. J. Range Manage. 7:152-154.

Morley, F.H.W. 1968. Pasture growth curves and grazing management. Aust. J. Exp. Agr. and Anim. Husb. 8:40-45.

Morris, R.M. 1969. The pattern of grazing in continuously grazed swards. J. Br. Grassland Soc. 24:65-76.

Noy-Meir, I. 1976. Rotational grazing in a continuously growing pasture: A simple model. Agr. Syst. 1:87-112.

Painter, E.L., and J.K. Detling. 1981. Effects of defoliation on net photosynthesis and regrowth of western wheatgrass. J. Range Manage. 34:6871.
Robinson, G.G., and I.H. Simpson. 1975. The effect of stocking rate on animal production from continuous and rotational grazing systems. J. Brit. Grassland Soc. 30:327-332.

Rogler, G.A. 1951. A twenty-five-year comparison of continuous and rotational grazing in the Northern Plains. J. Range Manage. 4:35-41.

Savory, Allan. 1978. A holistic approach to range management using short duration grazing. p. 555-557. In: Proc. Ist Internat. Rangeland Cong. (Ed. by D.N. Hyder). Soc. Range Manage. Denver, Colo.

Sims, P.L., G.R. Lovell, and D.F. Hervey. 1971. Seasonal trends in herbage and nutrient production of important sandhill grasses. J. Range Manage. 24:55-59.

Sims, P.L., J.S. Singh, and W.K. Lauenroth. 1978. The structure and function of ten western North American grasslands. I. Abiotic and vegetational characteristics. J. Ecol. 66:251-285.

Smoliak, S. 1960. Effects of deferred-rotation and continuous grazing on yearlong steer gains and shortgrass prairie of southeastern Alberta. J. Range Manage. 13:239-243.

Snedecor, G.W., and W.C. Cochran. 1967. Statistical methods. 6th ed. Iowa St. Univ. Press., Ames. 593 p.

Spedding, C.R.W.1965. The physiological basis of grazing management. J. Br. Grassland Soc. 20:7-14

Steeter, C.L., D.C. Clanton, and O.E. Hoehne. 1968. Influence of advance in season on nutritive value of forage consumed by cattle grazing western Nebraska native range. Univ. of Nebraska Agr. Exp. Sta. Res. Bull. 227. $21 \mathrm{p}$.

Voisin, André. 1959. Grass productivity. Philosophical Library Inc. New York. N.Y. 353 p.

Walker, B. 1968. Grazing experiments at Ukiriguru, Tanzania. II. Comparisons of rotational and continuous grazing systems on natural pastures on hardpan soils using an "extra period Latin-square change over design". E. Afr. Agr. Forest J. 34:235-244.

Wallace, J.D., D.N. Hyder, and G.V. Van Dyne. 1972. Salivary contamination of forage selected by esophageal fistulated steers grazing sand hill grassland. J. Range Manage. 23:424-430.

Willoughby, W.M. 1959. Limitations to animal production imposed by seasonal fluctuations in pasture and by management procedures. Aust. J. Agr. Res. 10:248-268.

CHANGE OF ADDRESS notices should be sent to the Managing Editor, 2760 West Fifth Ave., Denver, Colo. 80204, no later than the first day of the month of issue. Copies lost due to change of address cannot be replaced unless adequate notice is given. To assure uninterrupted service, provide your local postmaster with a Change of Address Order (POD Form 3575) indicating thereon to guarantee forwarding postage for second-class mail. 